HORVÁTH Cz. János

\title{
A digitális kitǔző- és tanúsítványtárak problematikája és megoldási lehetőségei
}

\begin{abstract}
Bevezetés
A Budapesti Múszaki és Gazdaságtudományi Egyetem Mérnöktovábbképző Intézet (BME MTI) részvételével zajló DISCO VET projekt[1] keretén belül kitűzött cél egy Open Badge szabványra épülő digitális kitűző és tanúsítvány-kezelő rendszer kialakítása. Nyílt forráskódban elérhető Badgr program képességei jelentik az alapszintet, de ezek továbbfejleszthetők. A képzési folyamatok eredményes teljesítésekor kiállítható digitális kitűzők (tüzzencsek, tanjelvények) kezelésének könnyítésére, általános használatba vételéhez, a közhasználatba való elterjesztéséhez megfelelő szolgáltatás, platform építhető.
\end{abstract}

\section{Történeti összefoglaló}

Az általános vélekedés szerint a digitális kitűzők első igazi színre lépésének pillanata a Mozilla Alapítvány és Peer 2 Peer University közös írásának megjelenéséhez köthető. Az „An Open Badge System Framework" címú munkájukban a kitǔzőt a teljesítmény, képzettség, minősítés jeleként vagy fokmérőjeként értelmezték[2]. Mivel a kitűzők az online térben is kezelhető objektumok, és köthető hozzájuk valamilyen teljesítmény, így értékké válnak, ebből következően érdemessé a gyűjtésre. A tanulást ösztönzi, mivel az elért teljesítmény képi alakba öntött mércéjeként könnyen bemutatható és összevethető mások szintjével. Ebben az írásban fogalmazták meg azt is, hogy a digitális kitűzők mögött olyan szolgáltatásokat kell üzemeltetni, amelyekkel bárhol és bármikor elvégezhető e kitűzők hitelesítése és ellenőrzése. Feltétlenül szükséges információ arról, hogy ki kapta meg az adott kitúzőt, mi a kitűző mögötti teljesítmény, ki volt a kibocsátó, hogyan és mikor állították ki, és lehetőség szerint bemutatni, hogyan dolgozott meg a kitűző által szimbolizált teljesítményért a tulajdonos (például tantervek bemutatása).

A Mozilla Alapítvány 2012-ben jelentette be az „Open Badge 1.0” szabványt, amely a fent szempontok szerinti rendszer múszaki kivitelezésének fő támpontjává vált. 2013-ra 1450-nél több szervezet állított ki digitális kitűzőt. 2014-re alakult meg az Open Badge szabványt fejlesztését felvállaló szervezetek és egyének szövetsége, a Badge Alliance. Szintén 2014-ben társult a Concentic Sky és az edX, hozzájuk fúződik a Badgr, amely nyílt forráskódú programként kíván mintaként szolgálni a szabvány helyes megvalósítására. 2015-ben az IMS Global Learning Consortium bejelentette elköteleződését az Open Badge irányában, mert a tanúsítványok nemzetközi átjárhatóságát ilyen alapokon látta megvalósíthatónak. Ez a kötődés olyan erőssé vált, hogy 2018. február $27-e ́ n$ bejelentették a szabvány 2.0-ás változatát, amelynek további gondozását folyamatosan végzik[3].

\section{Open Badge Hollandiában}

Világszerte egyre több képző intézmény szerez tapasztalatokat a digitális kitǔzők kapcsán. Hollandiában létrejött az úgynevezett SURF szövetség a képző és kutató intézmények (kutatóegyetemek, tudományegyetemek, szakképző intézmények, orvostudományi egyetemek, kutatóközpontok) közremúködésével. E szervezet célul tűzte ki az élenjáró technológiák alkalmazásával a széles körű tudás- és ismeretterjesztést a folyamatos fejlesztések mellett[4]. A fejlesztések egyik eredménye, hogy a képző intézmények úgynevezett edubadge-eket (magyarul tanjelvénynek fordíthatnánk) bocsáthatnak ki. A digitális kitűzők nemzeti szintű támogatottságának 
kialakítása példaértékü, a "7 Arguments For A National Approach To Open Badges In Education” kiadványukban a következő szempontokat emelik ki.

- Átláthatóbbá válik a tudás és képzettség rendszere.

Mivel az életen át tartó tanulás széleskörüen elfogadottá válik, a formális képzésen túl, akár külföldön is szerezhetnek ismereteket, végzettségeket a tanulók. Ezen eredmények összegyűjtése és tetszőleges időben és helyen való felmutatása szükségessé válik, ebben kaphatnak segítséget és támogatást.

- Könnyebbé válik az átjárhatóság a különböző képző intézmények között.

Elfogadottá vált a képzés különböző szakaszainak más intézményben történő folytatása, például a mester fokozat megszerzése esetében. A tanjelvények segítségével a felsőoktatás intézményei számára rálátásuk nyílik az adott hallgató korábban megszerzett ismereteire, azok minőségére, így a felvételi folyamat is egyszerúbbé válhat. Emellett a munkaerőpiacon is fontos szerep jut ennek, hiszen a munkakezdő egyén képességeinek, tudásának összességét egy tanjelvény gyújtemény jól mutatja be a munkaadó számára.

- Kisebb eröfeszítéssel lehet megoldani a képzésszervezést.

A SURF-ban résztvevő oktatási intézmények számára könnyebb egy digitális kitűző kiadása, a központi digitális közmű támogatása által. Digitális kitűzőt tetszőleges céllal és számban állíthatnak ki, például mikrotanúsítványok digitális kifejezésére is. A mikrotanúsítványok (microcredentialing) esetében a hagyományos formális képzések kisebb, önmagukban is értékes egységekre tagolódnak, amelyek sikeres teljesítésével pontosabban követhető és nevesíthető a tanuló által megszerzett ismeretek és tudás rendszere.

- A digitális kitǔzők értékállóságának biztositása.

A tanjelvények valódisága és megbízhatósága kiemelt szempont a SURF rendszerben. A szövetség által üzemeltetett digitális közműben a résztvevők hatékonyan rendezhetik a kitűzőkkel kapcsolatos teendőiket, miközben a technológia biztosítja a digitális védelmet.

- Jól szervezett hitelesítés, ellenörzés és adatvédelem.

A tanjelvények birtokosait és más felhasználókat biztosítani kell az adott digitális kitǔzők érvényességéről, hitelességéről, ellenőrizhetőségéről. Mindamellett ügyelni kell a GDPR szempontokra is, így minden résztvevőtől be kell szerezni az adatfelhasználási engedélyeket a tanúsítványok és kitűzők kiállításakor.

- Nemzetközi szabványok követése.

Az oktatás világa a nemzetközi térben helyezkedik el, így a SURF által kezelt tanjelvényeknek illeszkedniük kell a nemzetközi elvárásokhoz, jelen esetben az IMS Global Learning Consortium $\begin{array}{llllll}\text { által gondozott } & \text { Open } & \text { Badges } & 2.0 & \text { (OBv2) szabványhoz }\end{array}$ (https://www.imsglobal.org/activity/digital-badges). A tanjelvényeknek tartalmazniuk kell az európai kétszintű egyetemi rendszernek megfelelő a kulcsinformációkat, amelyek között megjelenik European Credit Transfer System (ECTS) szerinti kreditérték, valamint az elért tanulási kimenetek leírásai is. A SURF rendszer szorosan együttmúködik az Európai Bizottság EUROPASS munkálataival, ahol a SURF-höz hasonló, de európai látókörű kezdeményezés kezdődött el.

- A nyílt forráskódnak köszönhető a gyors és könnyü együttmüködés képessége.

A SURF kezdetektől fogva a nyílt forrásra alapozta a sikerét a sikeres együttmúködés és a szolgáltató-függetlenség érdekében. Ezért döntöttek a Badgr cég és a szolgáltatása[5] mellett az indulás időpontjában.

\section{További alkalmazási szempontok}

A digitális kitűzőknek további felhasználási területei is lehetnek az elsődleges célon túl.

- Résztvevők ösztönzése, motiválása a közremúködésben. A legtöbb kitűzőt megszerző egyén különböző elismerést kaphat.

- Együttmüködés ösztönzése az online kommunikáció során. Megfigyelhető jelenség, hogy az online térben kis számú csoport hozza létre a hozzászólások és bejegyzések többségét, így 
torzíthatják, befolyásolhatják a többség alapvető véleményét. Ezt ellensúlyozhatjuk kitűzőkkel, ösztönözve a csendes többséget a kommunikációban való részvételre.

- Értékelés területén is dolgozhatunk kitűzőkkel, ezekre ugyanis tekinthetünk olyan eszközként, amely rögzíti a minősítést, bizalmat ébreszt, vagy díjként adható. Az oktatás világában számos értékelés keletkezik, ezek lehetnek diagnosztikusak (helyzetfeltáróak), formatívak (fejlesztőformálóak) és szummatívak (lezáró-minősítőek). A digitális kitűzőket gyakran kapcsolják össze a formatív értékeléssel, ahol az egyén tanulmányi előrehaladását követve kaphat visszajelzést. A tömeges nyitott online képzések (MOOC) esetén ez teljesen megszokott megoldás. Természetesen más értékeléstípusoknál is létjogosultsága van a kitǔzőknek.

- Másodlagos tanúsítványnak is beillenek egy olyan képzési programban, ahol hagyományosan a papír alapú diploma számít elsődleges minősítő, értékelő okiratnak.

- Képzettségmutató eszközként is alkalmazhatóak, főleg olyan általános képzési folyamatban, ahol általában egy egyszerü ,megfelelt - nem felelt meg” minősítést szerezhet a résztvevő. A digitális kitűzők sokrétübben mutathatják be egy adott képzettség elsajátított szintjeit.

\section{Mi a digitális kitüző?}

A digitális kitúző meghatározására számos mód létezik. A digitális kitűző egy eszköz, amely által az elért teljesítmény vagy tudás megjeleníthető, hozzáférhető, ellenőrizhető, akár valós időben, online módon. Ezeket a kitǔzőket változatos környezetekben lehet megszerezni, leginkább internetes oktatási felületeken keresztül [6].

A digitális tanúsítványok (digital credentials) rendszere nem korlátozódik szúken a digitális kitűzőkre (digital badges), amelyek az előbbinek egy részhalmazát adják. Az 1. ábra segít a felosztás megértésében.

1. ábra: A tanúsítványok nagy rendszere, amelynek csak egy kis szelete a digitális kitǔzők világa

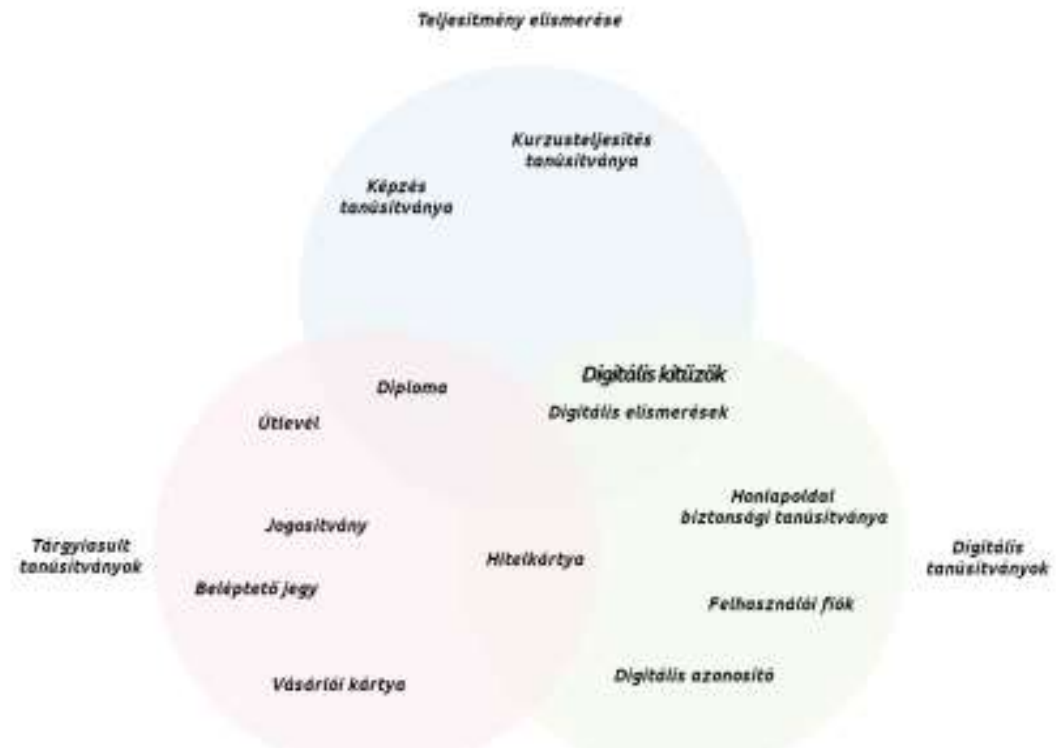

Forrás: a [7] oldalon elérhető „A comprehensive guide to digital badges” kiadvány ábrája alapján saját feldolgozás.

A digitális tanúsítványok a tárgyiasult tanúsítványok digitális változatai. Ebbe a körbe sok minden beletartozik, például a jogosítványok, útlevelek, személyi igazolványok. A digitális tanúsítványok ezek digitális megfelelői, bizonyítva azok tulajdonosának valamilyen képesítését, végzettségét, megszerzett engedélyét, szaktudását. Gyakorlati hasznuk, hogy sokkal gyorsabb és egyszerúbb az ellenőrizhetőségük a papír változathoz képest. Természetesen ugyanúgy tárolják a tulajdonos nevét, a tanúsítás célját, a kibocsátó megnevezését, szükség esetén a lejárati időpontot. 
A [7] szerint három fő területet különböztethetünk meg a digitális tanúsítványok terén. Ellenőrzött digitális tanúsítványok (Test-Based Digital Credentials) azok, amelyeket felügyelt és ellenőrzött körülmények között tett vizsgával (írásban, szóban, gyakorlatban) szerzett meg az egyén, számot adva valamilyen tárgybeli tudásáról. A digitális elismerések (Digital Certificates) annyiban különböznek az előzőtől, hogy ebben az esetben nincs szükség a felügyelt körülmények között letett vizsgára. A digitális elismeréseket gyakran egy kurzus elvégzésekor bocsátják ki. A digitális kitűzők fő különbsége az előző kettőhöz képest az, hogy itt semmilyen papír alapú tanúsítványhoz nem szükséges megfelelni, csak az on-line térben léteznek, változatos megjelenési formákban. Ettől függetlenül kiállítható digitális kitǔző ellenőrzött vagy felügyelet nélküli teljesítmény elismerésére.

\section{A külcsín és a belbecs, vagyis a metaadatok}

Egy digitális kitűző két síkon értelmezendő. A látványos része a kép, amely a számítógép képernyőjén jeleníthető meg. A kevésbé szem előtt lévő, de annál fontosabb rész a metaadat-szerkezet. Az előbbi az ember által látható, olvasható, megfejthető adatokat hordozza, az utóbbi a kitűző digitális tanúsítványi mivoltát ellenőrző folyamatot hivatott támogatni. A 2. ábrán egy elvi vázlatot láthatunk.

2. ábra: Az Open Badge szabványnak megfelelő digitális kitǔző felépítésének elvi vázlata.

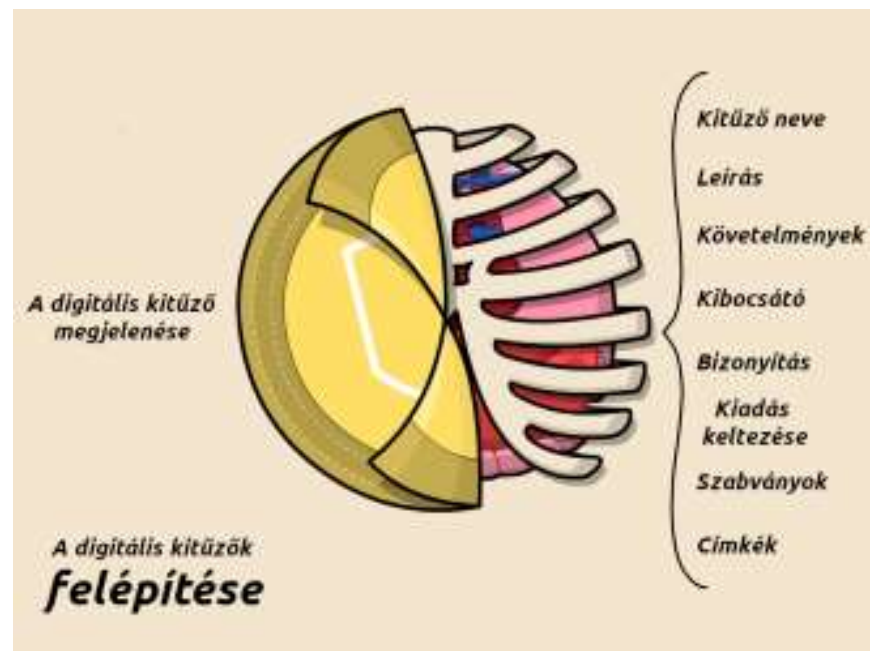

Forrás: a [8] alapján saját feldolgozás

Az Open Badge szabványnak megfelelő digitális kitǔző az alábbi metaadatokat tartalmazza:

- kitúző neve,

- követelmények (ez gyakran a leíró mezőbe kerül be),

- kitúző URL hivatkozása,

- kiadás keltezése,

- kibocsátó azonosítása (legalább a kibocsátó neve, de bármilyen beazonosító adat jó),

- kitűző birtokosa (a birtokoshoz köthető egyértelmú adatmező, pl. telefonszám, e-mail cím).

Amennyiben a kitűző célját, pillanatnyi állapotát is szeretnénk széles körben ismertté tenni, további metaadatok elhelyezése indokolt:

- alkalmazott szabványok,

- kiegészítő adatok a kibocsátóról,

- lejárati időpont,

- megszerzés tényéről bizonyíték,

- visszavonás és ennek indoklása,

- címkék. 
Ezeket az információkat a megfelelően előkészített képállományba lehet beírni, „beégetni”. A képállomány így már terjeszthető, hiszen tartalmazza azokat az adatmezőket, amelyekkel a tetszőleges ellenőrzés elvégezhető.

\section{A kitűzők életciklusa}

Az Open Badge szabvány meghatározza a kitűző (badge), a tanúsítvány (assertion) és a kibocsátó (issuer) fogalmát és egyben digitális leképezését (JSON állományok formájában). A 3. ábra a kitűző életciklusát mutatja be [9].

3. ábra: A digitális kitűző életciklusa

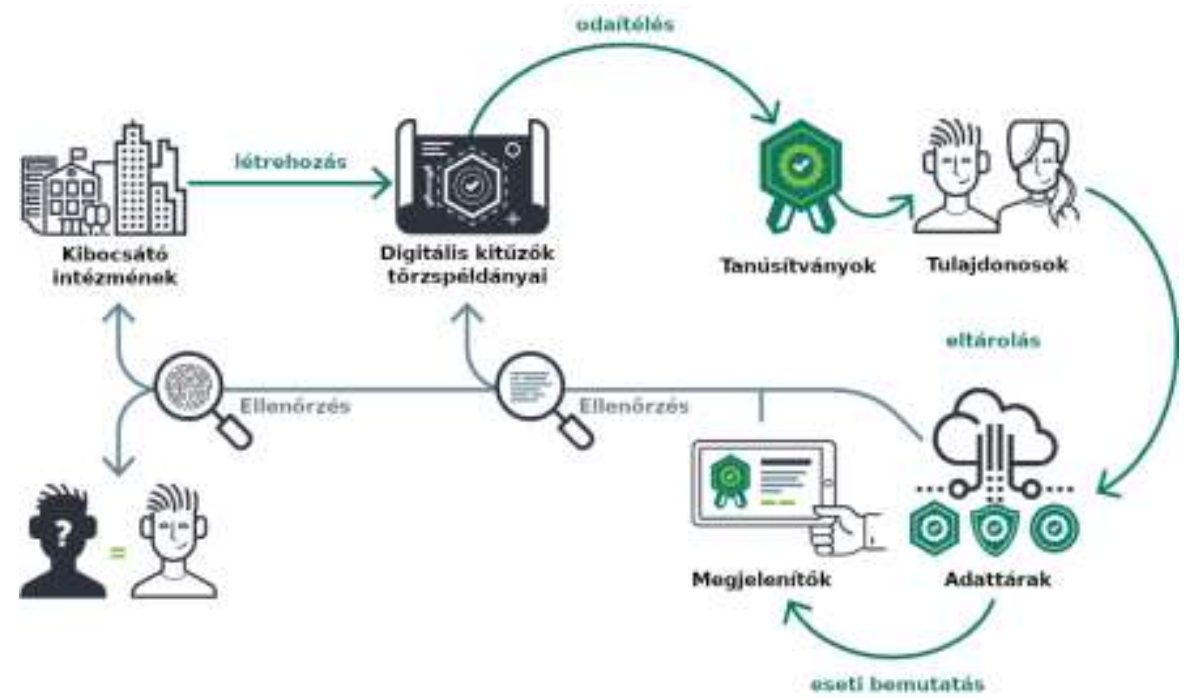

Forrás: A [9] alapján saját szerkesztés

A kibocsátók létrehozzák a kitúzőket, amelyeket a feltételek teljesülése esetén, a vonatkozó digitális tanúsítvány kiállításával adományozzák személyeknek. A kitűzők tárolása, bemutatása, valamint eredetének és jogos tulajdonosának ellenőrzése az ökoszisztéma része.

A kibocsátó intézmények megszabják a kitűzők megszerzéséhez szükséges feltételeket és követelményeket. A kibocsátás általában valamilyen online tanúsítvány-kezelő platformon keresztül zajlik. Ezek a platformok lehetővé teszik a kitűző arculati kialakítását, a kibocsátást, illetve a számos kitűző jogos tulajdonoshoz való eljuttatásának felügyeletét. A fejlettebb platformok képesek az elektronikus tanulmányi keretrendszerekkel (Learning Management System - LMS) szorosan együttműködni, így az adminisztráció még egyszerűbb egy kurzus teljesítésekor és a kitűzők szétosztásakor. Az adminisztráció általában a következő lépcsőkből áll:

- elismerésre váró szint vagy teljesítmény meghatározása,

- a kitűző megszerzéséhez szükséges követelmények összeállítása,

- követelmények és tananyagok alapján kurzus készítése,

- a tananyagok elérhetővé tétele a résztvevőknek (ez lehet ingyenes vagy térítéses, jelenléti vagy távoktatási forma),

- a beiratkozottak körében felmérni, kik teljesítették a kurzust és így jogosulttá váltak a kitúzőre,

- kitűző megtervezése és kibocsátása a megfelelő digitális tanúsítványkezelő platformon át.

Miután a kitűzőt odaítélték a tulajdonosnak, ő ezt tetszőleges módokon használhatja fel. Ez lehet a közösségi média, személyes honlap, e-mail aláírás, szakmai adatlapok vagy egy önéletrajz. A tulajdonosok gyakran kemény munkát fektetnek a tanulmányaik teljesítésébe, így nyilván minél több helyen akarják megosztani vagy csupán megjeleníteni az eredményüket megtestesítő kitúzőt. Mások azonban szükségszerúen meg kívánnak bizonyosodni ezen kitǔzők valódiságáról. 
Ha a kitűzőt nem lehet megosztani, vagy azok hitelességét külső felek nem tudják ellenőrizni, akkor ezek a tanúsítványok nagyon gyorsan elveszítik az értéküket. E helyzet elkerülésére nyújt segítséget az Open Badge szabvány alkalmazása. A külső felek számos, a hitelességet alátámasztó és így az egyén teljesítményét bizonyító metaadatot olvashatnak ki, például:

- a kitúző neve,

- a kitűzőt kibocsátó intézmény neve,

- milyen célból került kiállításra a kitűző,

- milyen munkát kellett a kitúző megszerzéséért elvégezni,

- a kitűző tulajdonosának neve,

- mikor állították ki a tanúsítványt, illetve mikor jár le.

A végső cél az, hogy a külső felek (például a jelenlegi vagy leendő munkaadók) közvetlenül ráláthassanak a digitális kitűzőkre, a mögötte lévő teljesítményre és megszerzett képzettségekre, valamint meggyőződhessenek mindezek valódiságáról, hitelességéről.

\section{Egy müködő Open Badge platform}

A Concentic Sky által fejlesztett Badgr alkalmazás az Open Badge szabvány teljes értékú megvalósításával egy példaértékủ alkotás a témakörben. Érdemes áttekinteni az egyes képességeket és funkciókat, így teljes képet alkothatunk a digitális kitűzők és az azokat kezelő platform lehetőségeiről.

Legelső lépésként keressük fel a https://info.badgr.com/ oldalt!

4. ábra: A Badgr alkalmazáshoz a nyitólap

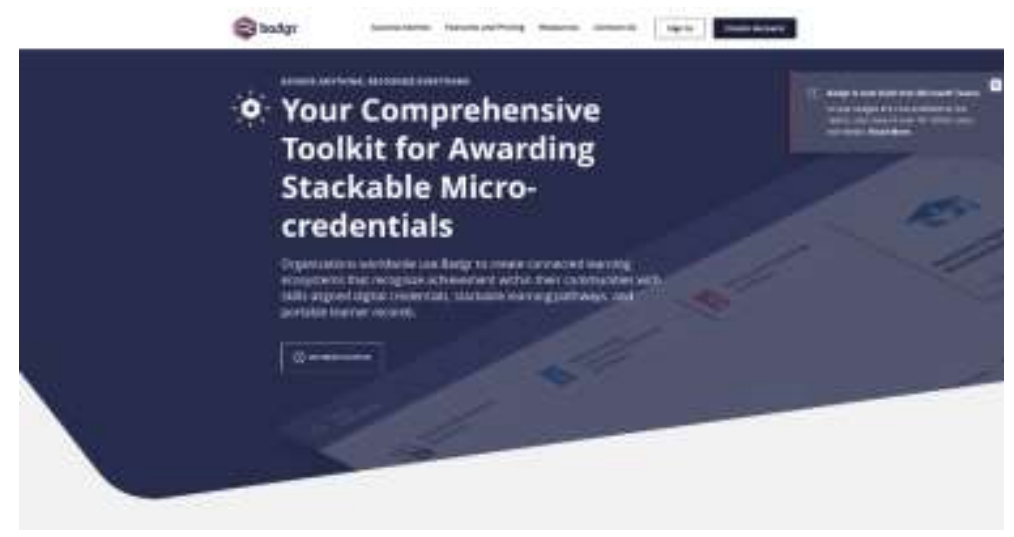

Az alkalmazás használatához hozzunk létre saját profilt a „Create Account” gomb használatával!

5. ábra: Saját profil létrehozása

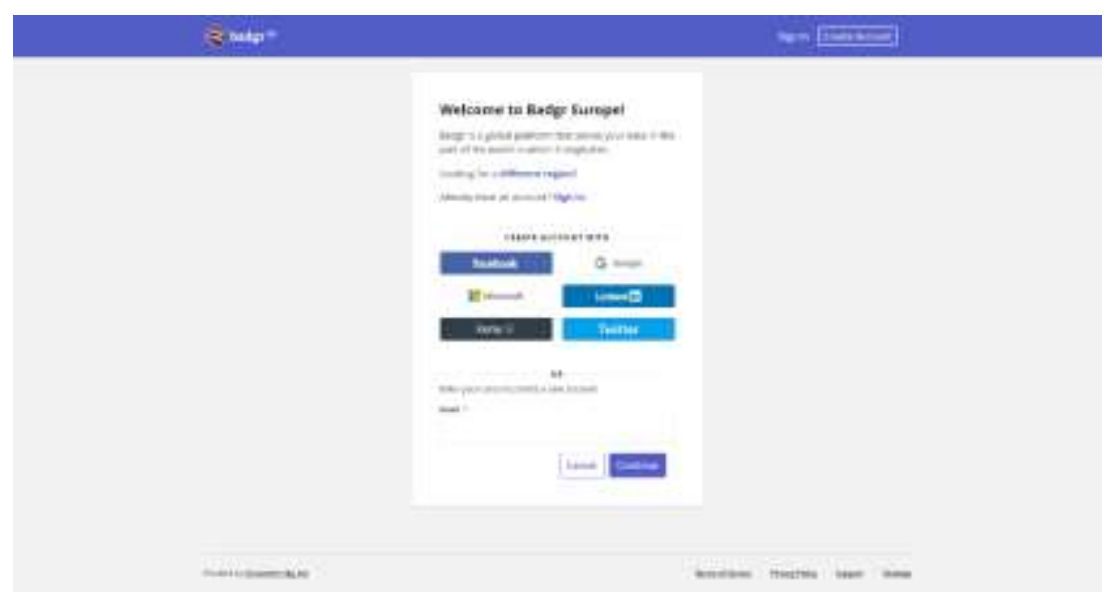


Itt kezdetben egy kapcsolattartó e-mail címet írjunk be, majd nyomjuk le a "Continue” gombot! Várjuk meg a címünkre érkező ellenőrző számsort, amelyet írjunk be a megfelelő beviteli mezőbe!

6. ábra: Ellenőrző számsor beírása

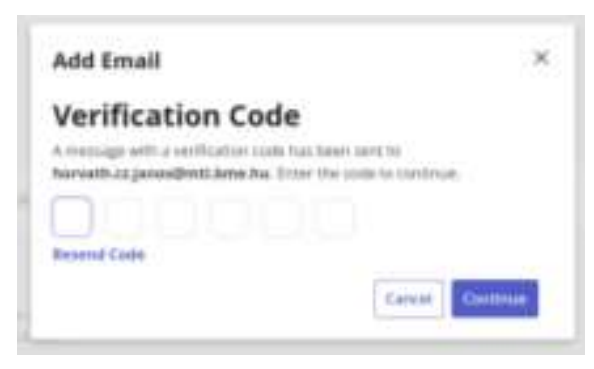

A sikeres bejelentkezést követően egy viszonylag üresnek látszó felület fogad minket, amely arra vár, hogy első digitális kitűzőnket feltöltsük. Már korábbról szereztünk kettő, névre szóló badge-et, így ezekkel dolgozunk a továbbiakban.

7. ábra: Kezdő oldal a „Backpack” felületen

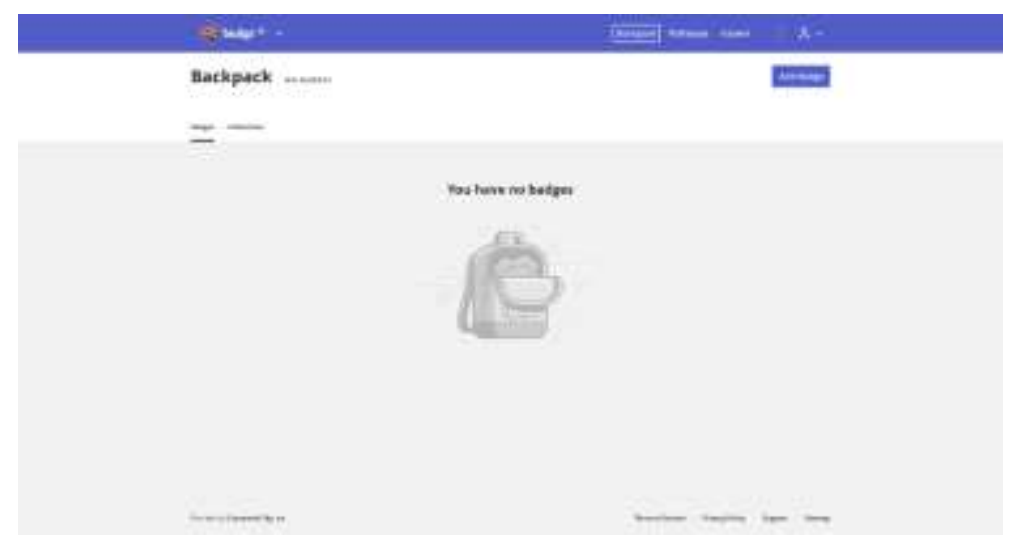

A felület neve „Backpack”, azaz hátizsák, ezt a tényt erősíti a kép közepére elhelyezett rajz is. Még a Mozilla Alapítvány kezdte a digitális kitűzők tulajdonosok általi gyŭjteményét így megnevezni, utalva arra, hogy e gyűjtemény a felhasználók által szabadon átvihető más adattárakba. Nos, töltsük fel ezt a hátizsákot! Ehhez használjuk az „Add Badge” gombot a képernyő jobb felső sarkában!

8. ábra: Párbeszédablak a kitűző feltöltésére

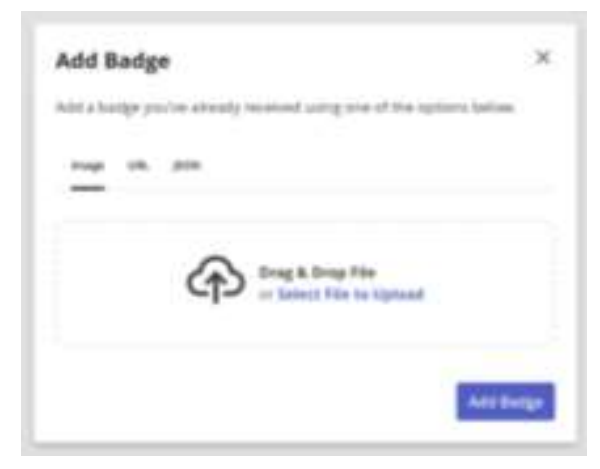

A feltöltés során a Badgr kiolvassa a képállomány metaadatait, és ha mindent rendben talál, jóváhagyhatjuk a feltöltést. 
9. ábra: Ellenőrzött kitǔző várja a feltöltés folytatását

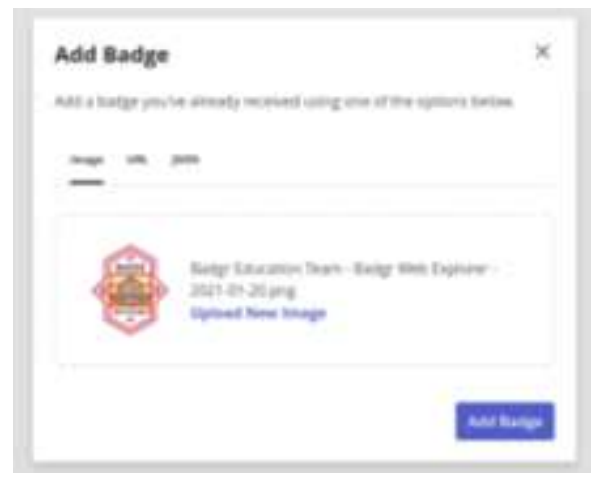

10. ábra: Sikeres feltöltés eredménye

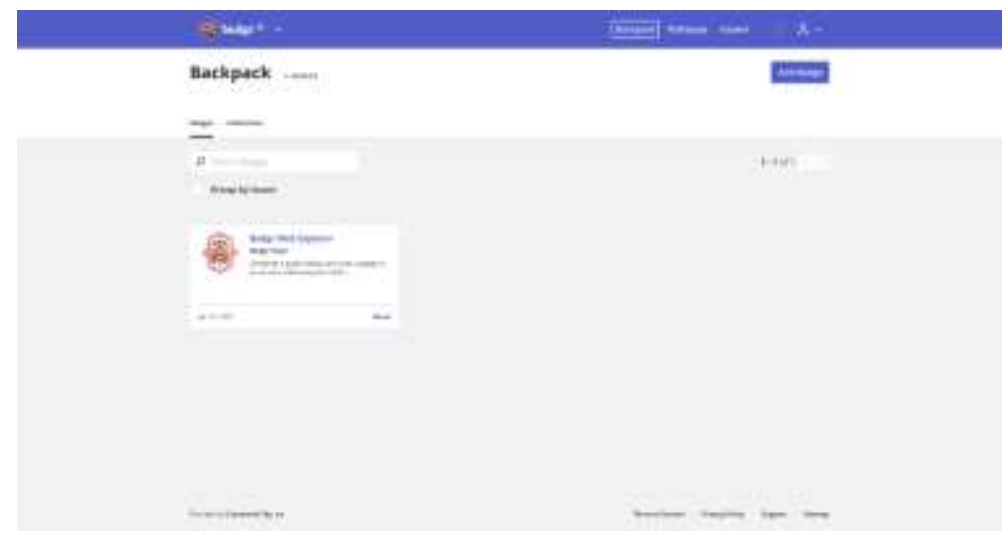

A sikeres feltöltést követően a „Backpack” felületen megjelent a digitális kitűzőnk. Ha rákattintunk, elolvashatjuk a részletesebb leírását. Ebben az új nézetben számos menüpont érhető el (többek között a megosztás, letöltés, nyomtatás, illetve a gyűjteményből való törlés). Először kattintsunk a „View Badge Public Page" ugrópontra, hogy a nyilvános nézetet megtekinthessük.

11. ábra: Részletek megtekintése

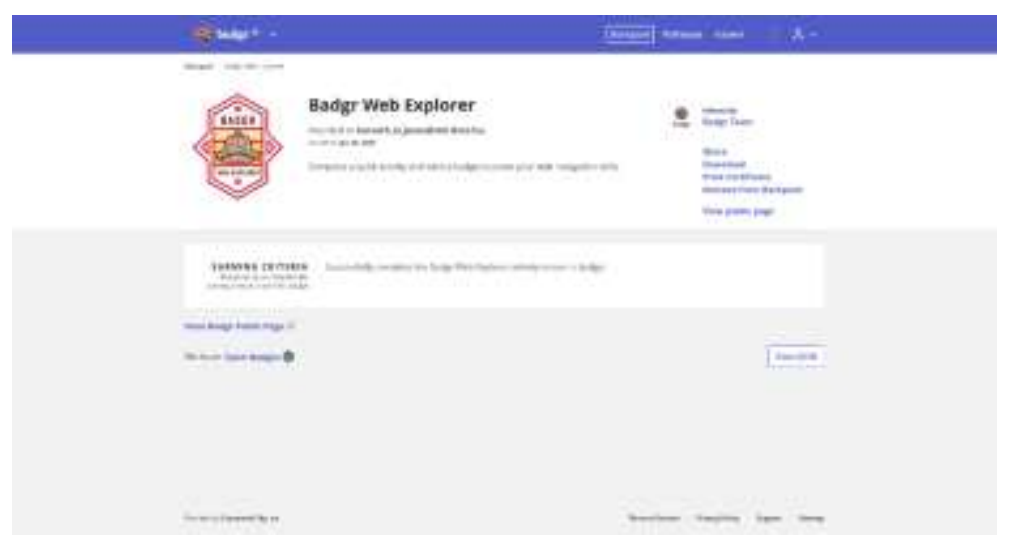

A részleteket megmutató képernyőről leolvashatjuk a nyilvánosan is elérhető adatokat, például mikor adományozták a kitűzőt, ki volt az adományozó, illetve az „Earning Criteria” melletti mezőben a teljesült adományozási követelményt. A képernyőn látjuk a kitǔző képét, valamint alatta nagy betűkkel a „Verified” (ellenőrzött) feliratot, biztosítva a megtekintőt a tanúsítvány hitelességéről. 
12. ábra: A kitűző részletes nézete

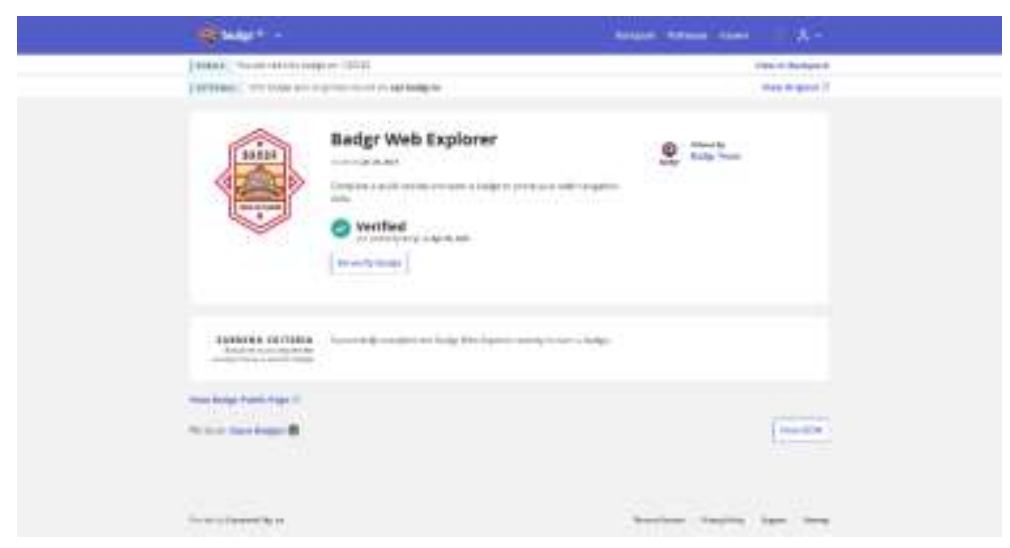

Amennyiben az átlagos érdeklődőkhöz képest kíváncsibban tekintünk a részletekre, úgy bátran nyomjuk meg a „Re-verify Badge” (kitűző újbóli ellenőrzése) gombot.

13. ábra: A kitűző újbóli ellenőrzése

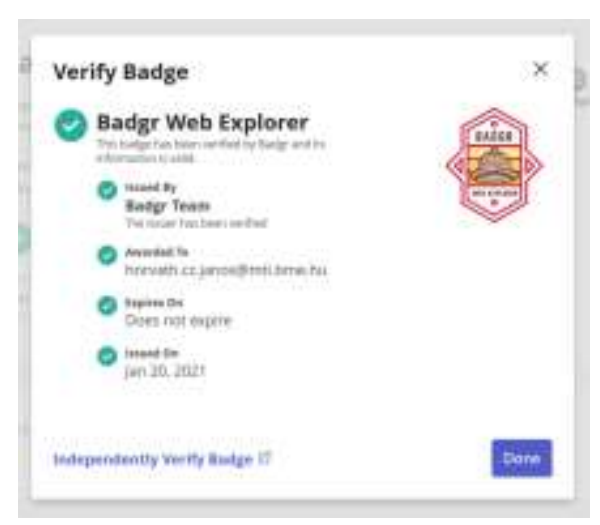

Az újbóli ellenőrzés során az adattár alkalmazás (jelen esetben a Badgr) lekérdezi a kibocsátó szervezetet a digitális kitűzőbe égetett metaadatok helyességéről és valódiságáról. További kitűzőt tehetünk a gyújteményünk részévé.

14. ábra: Két kitǔző a digitális hátizsákban

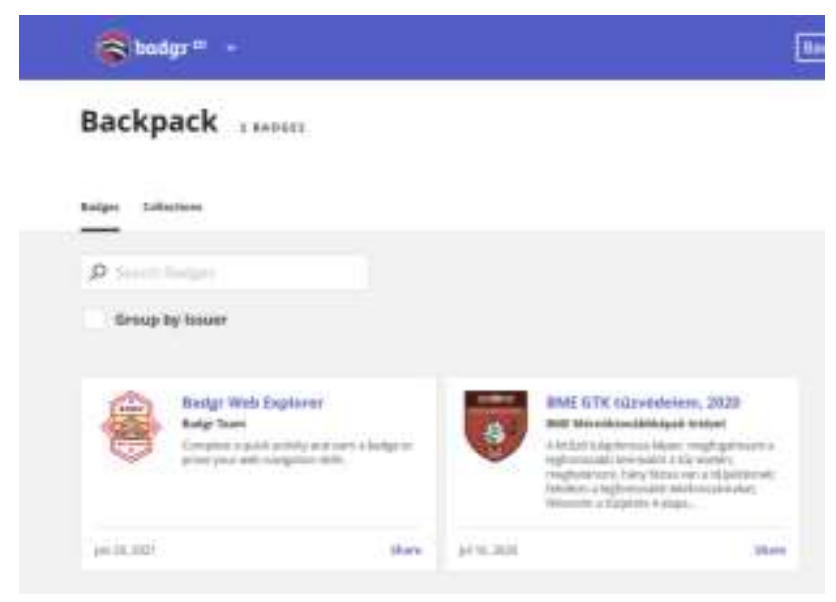

A gyakorlatban kettőnél jóval több digitális kitűzőre tehetünk szert, így hamar átláthatatlanná válna a gyưjteményünk. Lehetőség nyílik a „Collections” (összeállítások, albumok) menüpontban saját rendezett halmazokat meghatározni, amelyeket szintén megoszthatunk a külvilággal. 
15. ábra: Az összeállítások vagy albumok nyitólapja

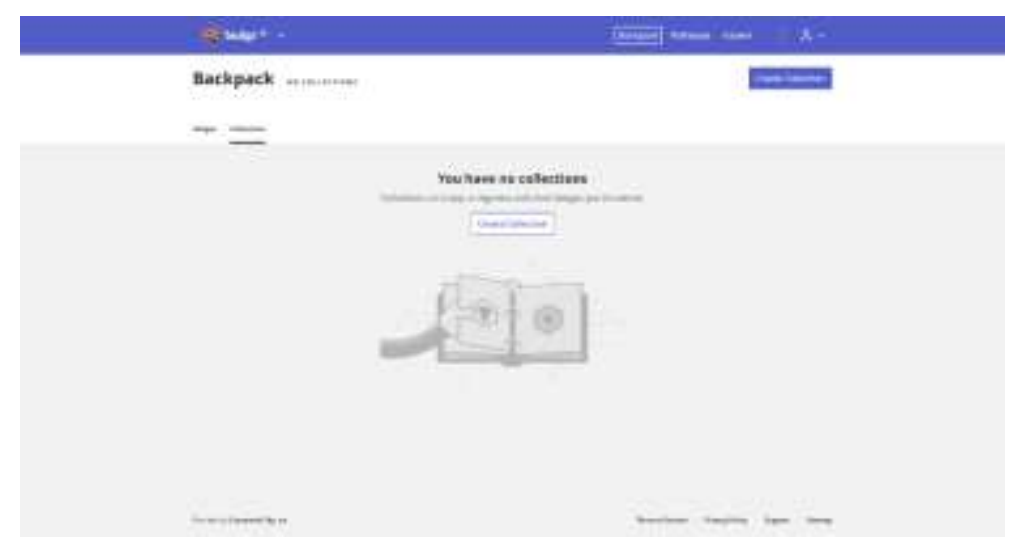

Az album rajz fölött nyomjuk meg a "Create Collection” gombot! A megjelenő párbeszédablak első mezőjébe („Collection Name”) az album nevét, a másodikba („Description”) a hozzá tartozó rövid leírást írjuk be. Használjuk a „Create Collection” gombot az adatrögzítéshez!

16. ábra: Album létrehozása

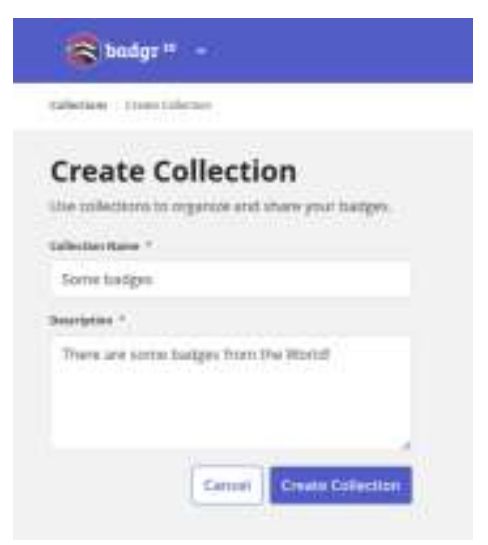

Visszajutunk a korábbi felületre, ahol az albumunk nevére kattintva újabb lehetőségként megjelenik a kitúzők albumhoz rendelési lehetősége. Használjuk az „Add Badges” gombot! A megnyíló párbeszédablakban a rendelkezésre álló kitűzők közül válogathatunk. A rögzítéshez alkalmazzuk az az „Apply" gombot!

17. ábra: Kitűzők albumhoz rendelése

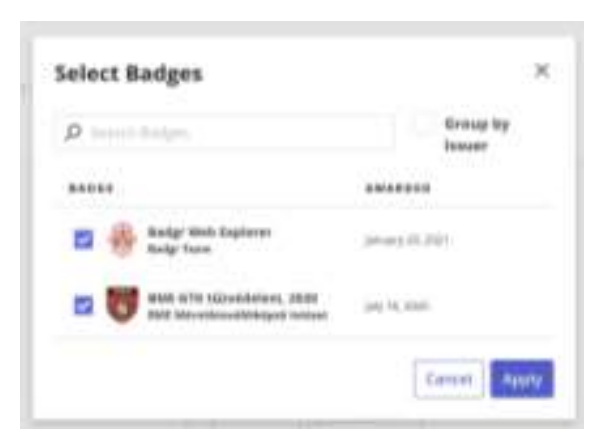

$A z$ „Apply” gomb utáni állapot a várakozásainknak felel meg. Az albumunk megosztására a „Share Collection" gombot használjuk a jobb felső sarokban! Az új párbeszédablak szerint három megosztás közül választhatunk. Közvetlen hivatkozással („Link”) a Badgr mutatja meg a gyújteményünket a 
külvilág érdeklődőinek, a közösségi média felületére a „Social” juttatja el tartalmunkat, de saját honlapunkra is beágyazhatjuk az összeállításunkat („,HTML”).

18. ábra: Album megosztásának három lehetősége

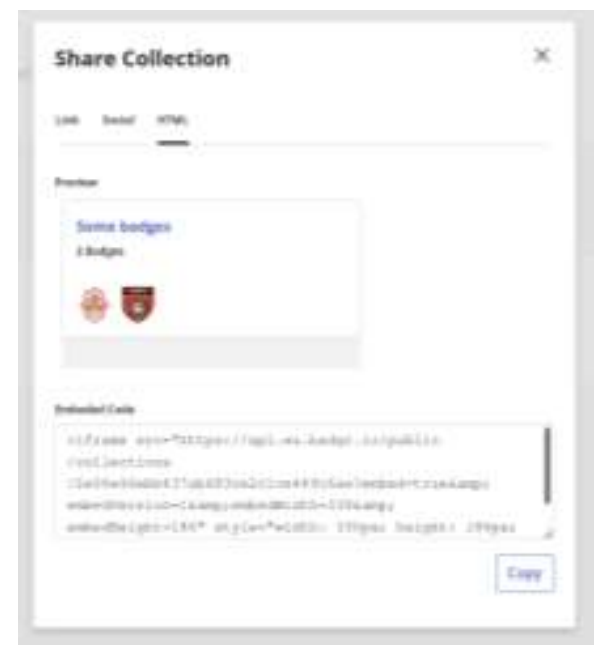

A Badgr profil segítségével mi magunk a tanúsítvány és kitúző kiállító intézmény szemszögéből is megtekinthetjük az Open Badge világot, ha a felső menüsorban a „Backpack” helyett az "Issuers” pontot választjuk ki.

19. ábra: Kibocsátó intézmény létrehozása

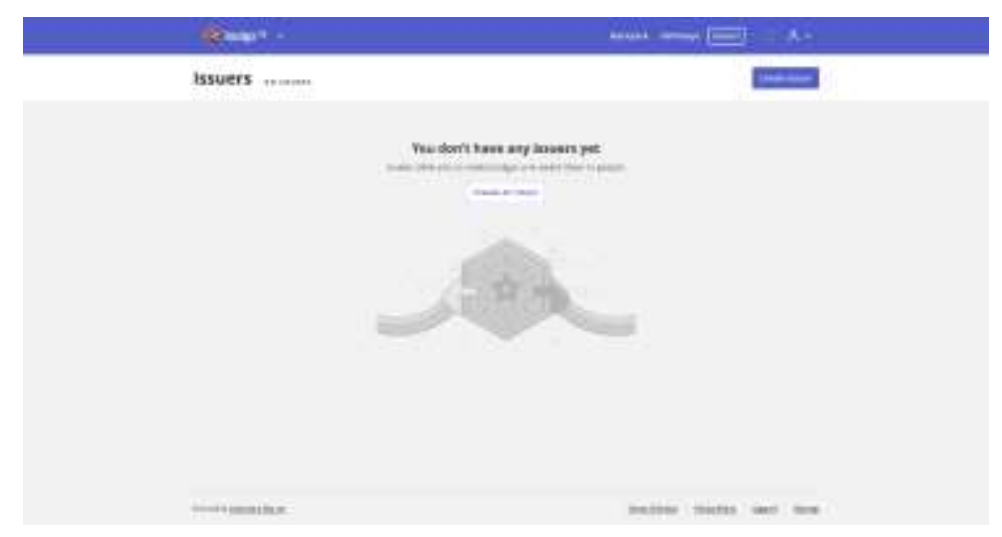

Kezdetben létre kell hoznunk az első kibocsátó intézményünket, ehhez nyomjuk meg a "Create Issuer” gombot! Az új felületen az intézmény adatlapját tölthetjük ki (az alábbi ábrákon kitalált adatokat használunk). Egy éles felhasználás esetén fontos a helyes és a minél részletesebb információk megadása, illetve a logók és egyéb képi jelek színvonalas megalkotása, hiszen ezek is az intézmény megítélésében játszanak - többnyire - komoly szerepet. Az adatok rögzítéséhez nyomjuk meg a „Create Issuer” gombot!

20. ábra: Kibocsátó intézmény létrehozása

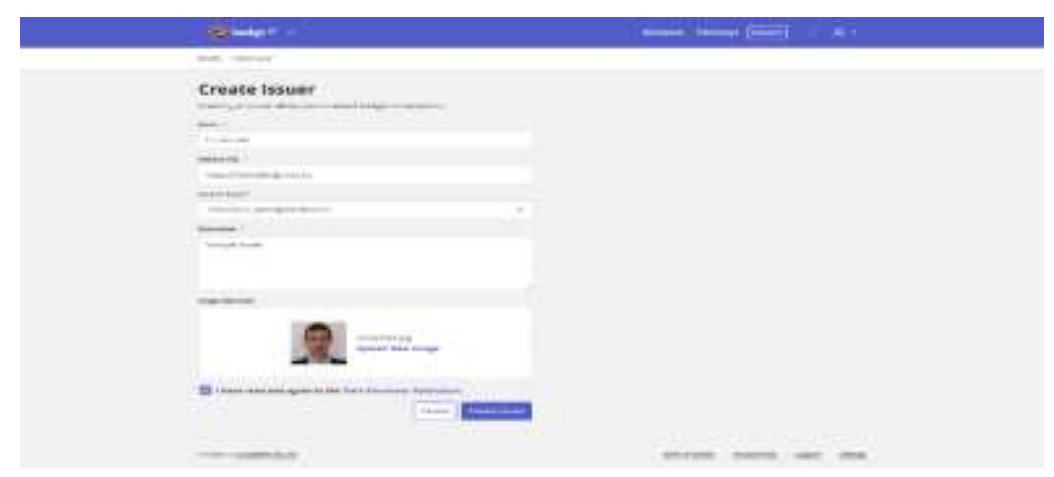


Ahogy a következő ábrán láthatjuk, a Badgr rendszerben létrejött az első kibocsátó szervezet. A következő teendő egy új kitűző törzspéldányának megalkotása. A Badgr nem kínál külön szerkesztői felületet a kitúző képi alakjának megrajzolásához. Ezt a fajta kreatív tevékenységet leggyakrabban szakemberekkel érdemes elvégeztetni, hiszen egy törzspéldány másolatai esetenként több száz érintetthez is eljuthatnak, nem érdemes figyelmen kívül hagyni itt sem a minőségi szempontokat! Most az egyszerűség kedvéért egy fényképet használunk. Használjuk a „Create Badge” gombot!

21. ábra: Kibocsátó intézményhez tartozó kitűzők létrehozása

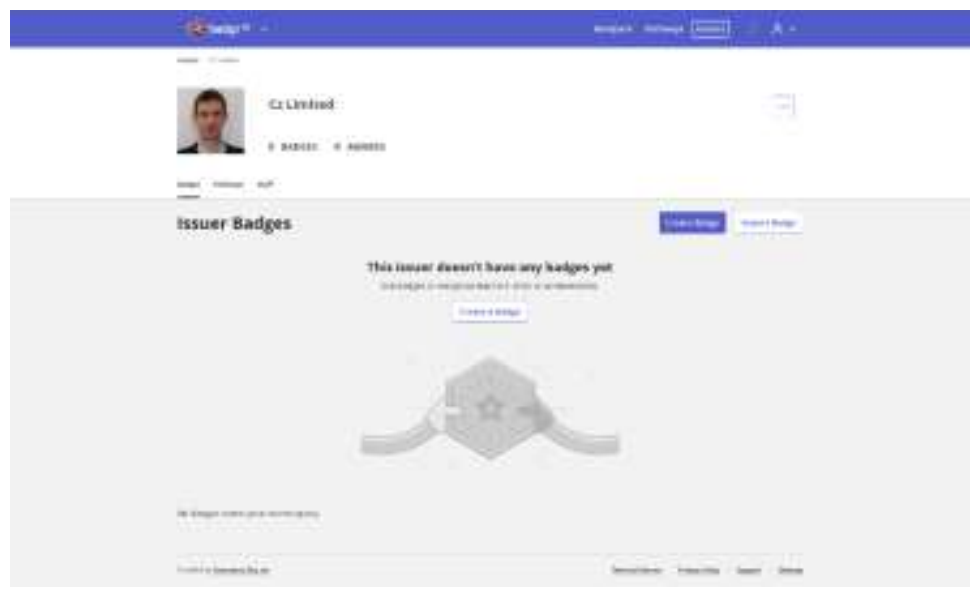

Az Open Badge szabványban meghatározott mezőket kéri kitölteni a megjelenő felület. Értelemszerúen megadandó a kitűző neve, illetve fel kell tölteni az arculatot jelentő képállományt. A „Description” mezőbe egy célratörően összefogott, de érdemi tájékoztatást adó szöveget ajánlott rögzíteni. Innen tudhatja meg mindenki, mit jelent a badge. A kötelező mezőkön túli ajánlott részekre is érdemes vetni egy pillantást. A „Basic Info" és az "Advanced Info" felületeken a szabványnak megfelelő kiegészítő tájékoztatást vihetünk be. Ilyen például az „Earing Criteria”, vagyis a megszerzéshez köthető követelmények (itt rögzíthetők azok a pontok, amelyek teljesítésével megkaphatja a tanuló a kitúzőt). Amennyiben minden lényeges adatot beírtunk, nyomjuk meg a "Create Badge" gombot!

22. ábra: Az első digitális kitűző törzspéldánya készül

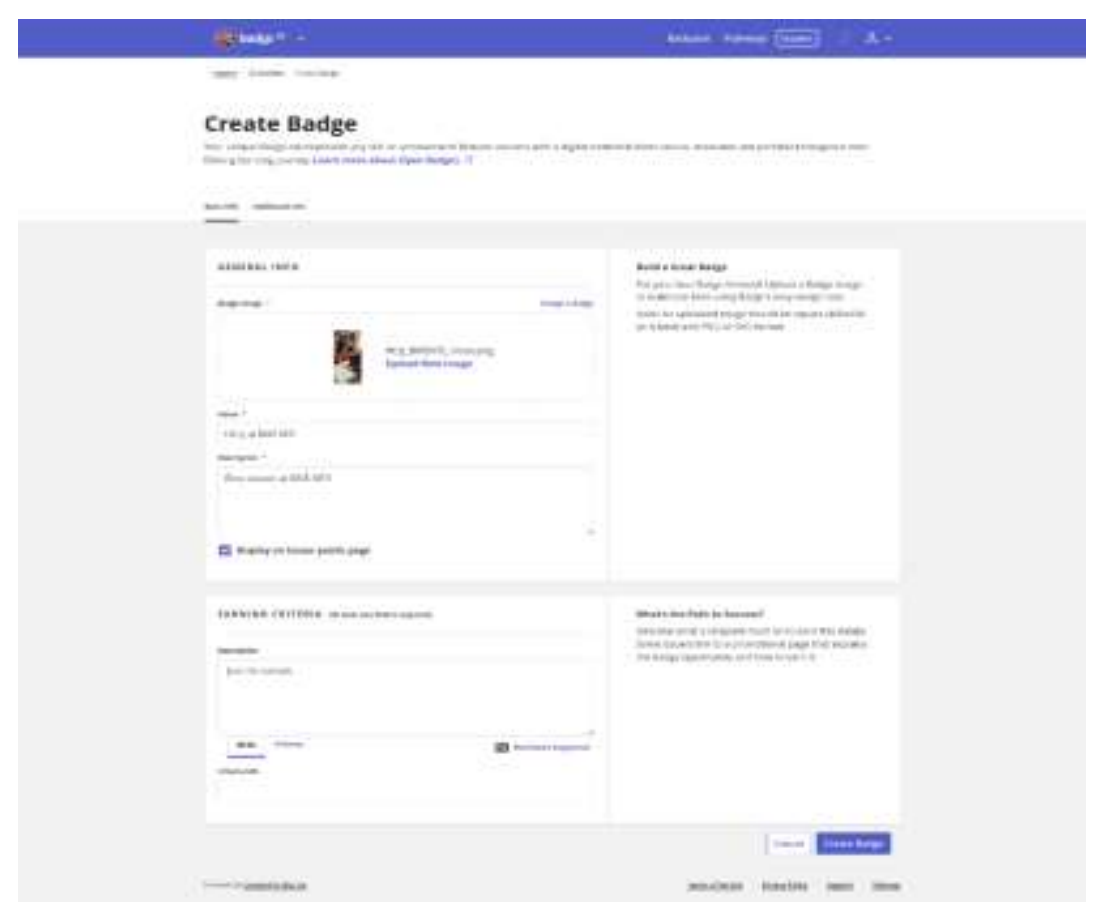


Visszatértünk a korábban megismert „Issuer” főoldalra, ahol arról olvashatunk, hogy az új kibocsátó intézményünk új kitűző-törzspéldánya alapján még senkit sem jutalmaztunk meg digitális kitűzővel. Tegyünk ezen ügy érdekében! Ítéljük oda valakinek a tanúsítványt az „Award Badge” gomb segítségével!

23. ábra: A törzspéldánya készült, egy példány odaítélésre vár

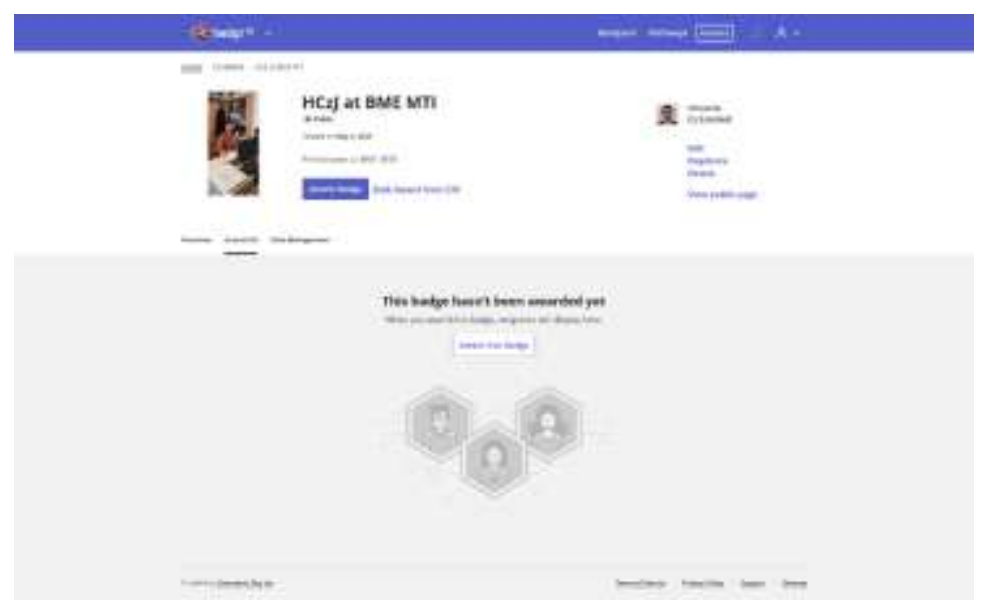

A már sokszor említett Open Badge szabvány megkövetel néhány fontos adatot az odaítélés folyamatában. Érdekes módon az adományozott neve tetszőlegesen elhagyható, annál lényegesebb az azonosítási mód megadása. Ez lehet e-mail, telefonszám vagy URL. Ezek mindegyike lehetővé teszi az egyén beazonosítását. Az URL esetén természetesen olyan internetes erőforrás-azonosítót kell megjelölni, amely segít a kétség nélküli beazonosításban (például egy tanulmányi keretrendszerben a felhasználó profiloldalának elérhetősége). A kibocsátás keltezése egyértelmű, a „Narrative” szakaszba a kitűző megszerzését indokló szöveges leírás kerülhet. Az „Evidence” szó szerint bizonyítékot jelent, itt pedig olyan információt, amely a kívüláló számára mutatja meg az adományozott általi teljesítmény részleteit (ez lehet a teljesített tanterv egy képzésben). Végül az „Expiration” mezőben az esetleges lejárati időpontot köthetjük ki. Használjuk az „Award Badge” gombot!

24. ábra: Az odaítélés ürlap oldala a Badgr rendszerben

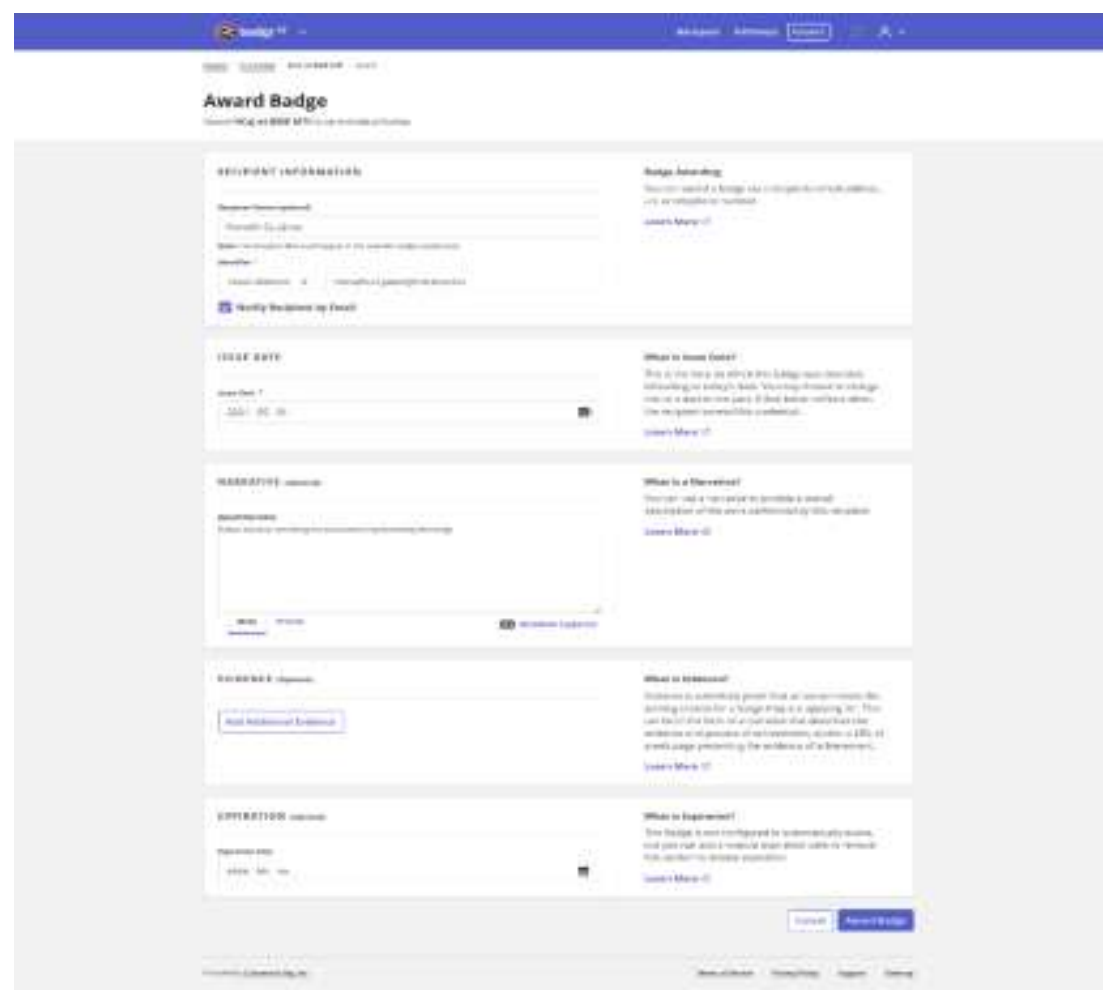


Az „Issuer” főoldal immár teljes! A törzspéldány alatt látható, kikhez került ki a digitális kitűző.

25. ábra: A kitǔző első sikeres adományozása megtörtént

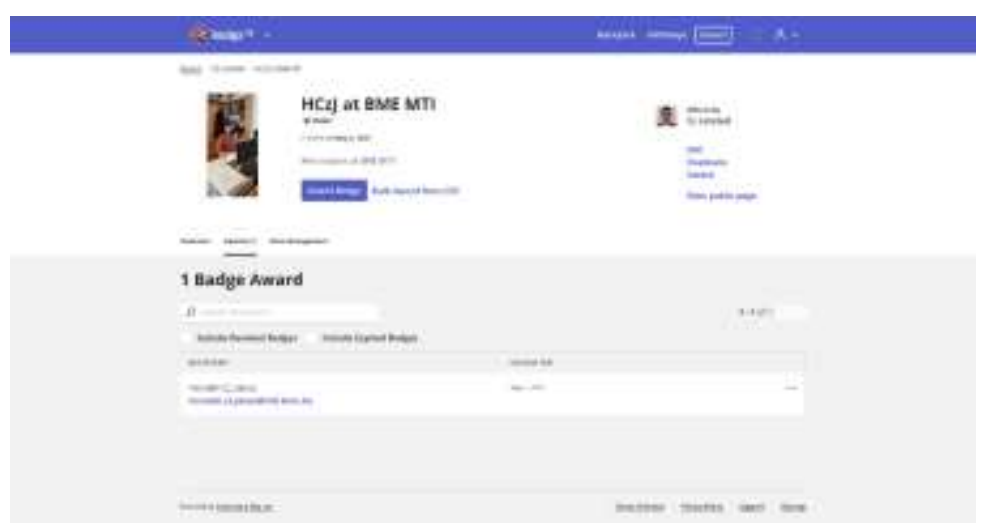

Minden kiosztás sorában egy szerkesztőpanel hívható elő a jobb oldalon, három pöttyön keresztül. A „Share” a kitűző megosztási lehetőségeit ajánlja fel úgy, ahogy ezt korábban a „Backpack” résznél láthattuk. A „Revoke” a tanúsítvány valamilyen megindokolt szándék szerinti visszavonására való. Vigyázat, a visszavonás eseményét nem javíthatjuk! A „Print Certificate” lehetőséggel a megszerzett tanúsítványunkat tekinthetjük meg nyomtatásra előkészített állapotban. Ez most egy oklevél forma, ahol szerepel a digitális kitúző képe, valamint az a néhány lényeges adat, amely a tulajdonos azonosítását lehetővé teszi. A nyomtatott példány kapcsolatát a digitális világgal a lap közepén-alján elhelyezett QR kód biztosítja.

26. ábra: A nyomtatásra kész tanúsítvány, rajta a digitális kitűző képével

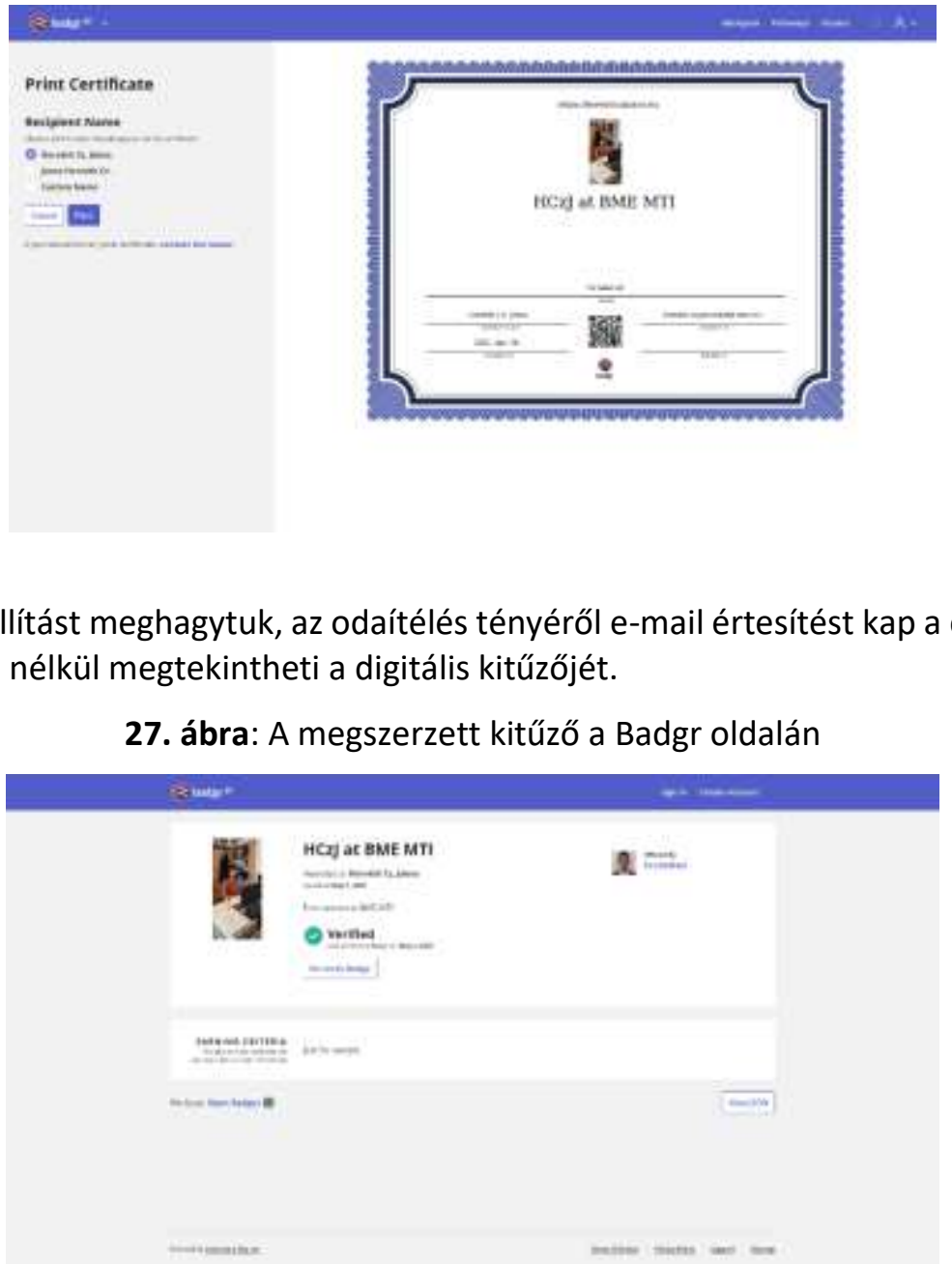

Ha a megfelelő beállítást meghagytuk, az odaítélés tényéről e-mail értesítést kap a címzett. Ő a Badgrbe való regisztráció nélkül megtekintheti a digitális kitűzőjét.

27. ábra: A megszerzett kitűző a Badgr oldalán 
Fontos megemlíteni, hogy adott a lehetőség a külső, független hitelesítésre is (hiszen megfelelő képességekkel megtévesztő honlapoldalakat is elő lehet állítani). A „Re-verify Badge” gomb segítségével eljuthatunk az Open Badge Validator 2.0 (https://badgecheck.io/) oldalra. Itt feltölthetjük a digitális kitǔzőnk állományát (talán érdemes újból megjegyezni, hogy az igazi, Open Badge szabványnak megfelelő digitális kitűző speciális képállománya tartalmazza azon metaadatok többségét, amelyekről jelen írásban már esett szó).

A hitelesítés sikeres tényéről a zöld visszajelzés nyugtathat meg minket. Érdekes tény, hogy a digitális kitűző ellenőrzése többirányú. Egyrészt a kibocsátó intézmény meglétét vizsgálják meg, másodszor a tanúsítvány törzspéldányának létezéséről győződnek meg, harmadrészt az adományozott kilétének felderítésére tesznek próbát. Ehhez az Open Badge Validator oldalon meg kell adni a beazonosításhoz szükséges adattartalmat (e-mail, telefonszám, URL). Ha ezt nem tudjuk vagy nem kívánjuk megtenni, a részleges hitelesítés még megtörténik.

28. ábra: A digitális kitűző hitelesítése független szereplő által

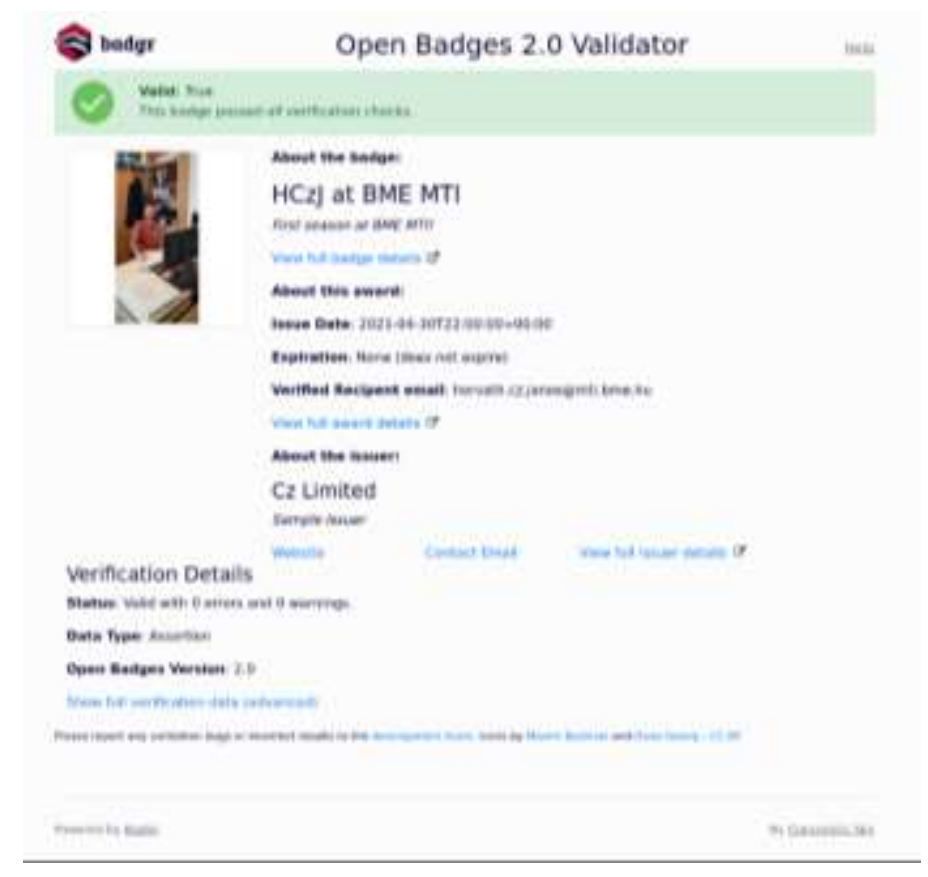

A Badrg a 3. ábrával szemléltetett életciklust támogatja, így a szabvány által kijelölt funkciókat maradéktalanul megvalósítja. Azonban nem biztos, hogy ennyivel beérhetjük, hiszen új igények bármikor jelentkezhetnek új felhasználási helyzetekkel együtt.

\section{Saját fejlesztés keretei}

A korábban említett Badgr program képes a teljes folyamatot kiszolgálni, jó példaként szolgál a rendszer bemutatásakor, azonban felmerülnek üzemeltetési nehézségek, ha nem a badgr.com felületen dolgozunk. A szabadon elérhető, nyílt forrású kódbázis olyan könyvtárakon alapszik, illetve a múködtetési környezet beállítása hosszú távon annyira nehézkesnek bizonyult, valamint a Badgr programszerkezetébe való bővítési lehetőségek olyan erőforrásokat kötne le, amelyek miatt életszerű gondolat saját kódbázison alapuló, új képességekkel könnyen bővíthető Open Badge variánst előállítani. Új funkciók az új felhasználási esetekből származhatnak. Ezek számbavétele következik.

Magyarországon a kialakult járványhelyzet miatt a digitális oktatás a köz- és felsőoktatásban gyökeret vert. Az ehhez kapcsolódó oktatási módszertanok alakulnak, fejlődnek. Megfigyelhetők a digitális információhálózat tömeges használatba vételével járó könnyebbségek mellett a nehézségek is (a figyelemmegosztás, a metakommunikációs csatornák beszúkülése, kiégés, demotiváció stb.). Kialakulatlan a különféle hagyományos vagy mikro képzettségek a digitális világban történő egyszerű 
bemutatási lehetősége. A számítógépes játékok, például MMORPG (Massively Multiplayer Online RolePlaying Game - nagyon sok szereplős online szerepjáték) esetében lehetőség van a játékvilágban zajló fejlődés képi nyomonkövetésére, amely a helyi közegben fokmérőnek bizonyulhat. A tanulás világában elért eredmények egyszerű, közérthető formában való bemutatása a digitális környezetben hasonló fokmérő lehet. A digitális kitǔzők elterjesztéséhez a köztudatban megfelelő ismeretközlő felület szükséges.

Amennyiben sikerül meggyőzni formális oktatást végző intézményeket (köz- és felsőoktatás, szakképzés, felnőttképzés, magáncégek stb.) a digitális kitǔzők értéknövelő fontosságáról az általuk kiállított tanúsítványokhoz, bizonyítványokhoz, úgy adja magát a következő eset, amelyben a kibocsátók kiszolgálását támogató platformot szükséges kialakítani. Ez a „digitális infrastruktúra szolgáltatás” lehetővé teszi az önálló kibocsátók tevékenységének nyomon követését, felügyeletét, segítését.

A kibocsátókat támogató platform adatgyűjtő hely is egyben, hiszen a GDPR szabályok betartása mellett számos statisztikai adat és kimutatás által a kibocsátók felé lehetséges megrendelői kéréseket is be lehet csatornázni, a kereslet-kínálat folyamatában egyfajta gyorsító tényezőként lehet megjelenni.

Az MKKR és EKKR figyelembevételével a digitális kitǔzők és tanúsítványok behatárolhatóvá, összevethetővé válnak. Amennyiben kormányzati törekvések hasznosnak találják, úgy a támogató platform a végzettségek összehasonlíthatóságának jó eszközévé válhat nemzeti és európai szinten egyaránt.

Az egyének szintjén a megszerzett kitűzők tárolásában a támogató platform szintén szolgáltatást nyújthat. A platformon belüli vagy azon kívüli kibocsátóktól származó kitűzők rendszerezése, megjelenítése mellett a kibocsátói kapacitások vagy a megrendelői igények is becsatornázhatók. Továbbá lehet egyfajta dicsőségtáblázatot vezetni, ajánlott képzettségek megszerzési útját kijelölni, a legtöbb, a legjobb és más szempontok szerinti rangsorokat készíteni, ezáltal egyfajta jó értelmü versengést kialakítani a résztvevők körében.

A digitális tanúsítványok kitúzőinek arculati megjelenítése, egyes példányok rajzolatának minősége befolyásolja a tanúsítvány szubjektív értékelését a tulajdonos vagy a külső szemlélő esetében. A digitális kitúző́k rajzolat-kialakításának támogatása a platform képességei közé kerülhet mint kapcsolódás képzőmúvészeti diszciplínákhoz.

A támogató platform üzemeltetője is állíthat ki digitális kitűzőket a kibocsátók, a résztvevő személyek, a képzések stb. irányában, egyfajta minőségbiztosítási tevékenységet gyakorolva ezzel.

A digitális (mikro)tanúsítványok mikrotartalmi szinten is megjelenhetnek, ennek lehetőségeinek feltárása további kutatást igényel.

\section{Összefoglalás és kitekintés}

Jelen írásban az Open Badge szabvány által biztosította keretben értelmezhető digitális kitűzőkről készült összefoglalás. Kitértünk a tanúsítványok egy lehetséges osztályozására és rámutattunk a digitális kitűzők és tanúsítványok helyére. Alkalmazhatóságukat a jelenkor eseményei egyre inkább indokolják, erre is adtunk példákat.

Az Open Badge szabványt megtestesítő, nyílt forráskódú Badgr részletes ismertetésén keresztül betekintést nyerhettünk ebbe az ökoszisztémába, rávilágítva arra a tényre, hogy a digitális kitűzők már „kulcsra készen” várják, hogy felfedezzük és használatba vegyük őket.

Bár teljes körúnek túnik a Badgr szolgáltatása, sajnos mégsem az. Az alapok jól kidolgozottak, mégis hiányosak, bár ez nem az ő hibájuk. Új felhasználási helyzetek alakulnak ki, ezekhez pedig többlet szolgáltatások szükségesek. A BME MTI a DISCO VET projektben való részvételének egyik velejárója a kitűzők hazai és nemzetközi alkalmazhatóságának felderítése, és a kihasználatlan lehetőségek beteljesítése. A DISCO VET keretében tervezett saját kódbázisú badge rendszer bemutatása egy következő jelentés tárgya lesz. 
Érdemes a kedves Olvasó figyelmébe ajánlani a téma szempontjából tovább kapcsolódási pontot. A MTA-BME Nyitott Tananyagfejlesztés Kutatócsoport (Open Content Development - OCD) [9] keretén belül már történtek kezdeményezések a digitális kitűzők új területeken történő hasznosítására. $A$ Kutatócsoport a nyitott tananyagfejlesztés új módszereit dolgozta ki az elmúlt években, főként a mikrotartalmakra helyezve a hangsúlyt [11] [12] [13]. Kifejezetten a digitális kitǔzők lehetőségeiről Zarka Dénes és Román Gábor írt remek összefoglalót a [14] kötetben, „Digitális kitűzők a mikrotartalmak értékelésében" címmel.

Felhasznál szakirodalom

[1] https://www.discovet.eu /

[2] https://wiki.mozilla.org/images/f/f3/OpenBadges -- Working Badge Paper.pdf

[3] https://www.imsglobal.org/ims-global-learning-consortium-announces-open-badges-20certifications

[4] https://www.surf.nl/en/

[5] https://info.badgr.com/

[6] https://www.accredible.com/wp-content/uploads/2018/07/A-Comprehensive-Guide-toDigital-Badges-Accredible.pdf

[7] https://www.accredible.com/wp-content/uploads/2018/07/A-Comprehensive-Guide-toDigital-Badges-Accredible.pdf

[8] https://classhack.com/post/45364649211/open-badge-anatomy-updated

[9] https://www.imsglobal.org/sites/default/files/Badges/OBv2p0Final/impl/assets/image1.png

[10] http://www.ocd.bme.hu/

[11] http://www.ocd.bme.hu/wp-content/uploads/2019/04/Tanterv-tananyagegys\%C3\%A9gmikro-tartalom-online-k\%C3\%B6rnyezetben.pdf

[12] http://www.ocd.bme.hu/wpcontent/uploads/2019/09/8.fuzet tervezet KADA vegleges2.pdf

[13] http://www.ocd.bme.hu/wp-content/uploads/2020/07/XIl. piros fuzet.pdf

[14] Benedek András (szerk): Új módszerek a szakképzésben - Kollaboratív online tartalom fejlesztés, Magyar Tudományos Akadémia és Budapesti Múszaki és Gazdaságtudományi Egyetem. Budapest, 2020. ISBN: 978-963-508-949-9. 